\title{
Abundance and diversity of amphipods (Crustacea: Peracarida) on shallow algae and seagrass in lagoonal ecosystem of the Mediterranean Tunisian coast
}

\author{
Wahiba Zaabar, Rym Zakhama-Sraieb", Faouzia Charfi-Cheikhrouha and Mohamed Sghaïer Achouri
}

\begin{abstract}
Background: Bizerte lagoon is a semi-enclosed marine ecosystem, where various types of human activities have been developed. To investigate the distribution and temporal variation of amphipod assemblage, monthly sampling was conducted at the Menzel Jemil site from October 2009 to September 2010.

Results: A total number of 3,620 specimens were collected from floating algae and seagrass allowing the identification of 10 amphipod species. Moreover, several indices, species richness, dominance, mean density, and diversity index were estimated to characterize the amphipode assemblage. Gammarus aequicauda was the most dominant species in all seasons. In addition, the minimum and maximum values of species richness of amphipod were observed in January (3 species) and April (8 species), respectively. The mean density and species richness were negatively correlated with plant biomass. Mean Shannon index $\left(H^{\prime}\right)$ and evenness $\left(J^{\prime}\right)$ were $1.62 \pm 0.34$ and $0.67 \pm 0.16$, respectively. Non-metric multidimensional scaling (MDS) analysis based on the mean species density showed three seasonal groups of samples. Therefore, canonical correspondence analysis (CCA) made it possible to summarize the overall situation for the species, monthly sampling, and environmental parameters on a single graph.
\end{abstract}

Conclusions: Thus, the temperature, turbidity, and chlorophyll a content are the most often reported factors for the distribution and structure of amphipods in the Bizerte lagoon.

Keywords: Coastal lagoon; Temporal distribution; Amphipod assemblage; Tunisia

\section{Background}

Wetlands are ecologically very important and extremely productive ecosystems, however very sensitive essentially in transitional locations subject to environmental and anthropogenic constraints (Mouillot et al. 2005; Rossi et al. 2006; Blanchet et al. 2008). The Tunisian lagoons, like several Mediterranean wetlands, are subject to an increasing pressure in the anthropogenic activities (urbanization, industry, pollution, aquaculture, tourism, and overfishing). The consequences can be detected on the general state of ecosystems, mainly in macrofauna that is more sensitive and more exposed (Ben Mustapha et al. 1999; Ayari and

\footnotetext{
* Correspondence: zakhamarym@yahoo.fr

S11UR11 Bio-Ecologie et Systématique Evolutive, Département de Biologie Animale, Faculté des Sciences de Tunis, Université Tunis El Manar, 2092
} Manar II, Tunis, Tunisia
Afli 2003). In the last decades, Bizerte lagoon in the northeast of Tunisia is the best example that illustrated the disturbances that were mainly caused by the worn water rejections coming from the bordering cities (Dellali et al. 2001), the naval port and the metallurgic factory of Menzel Bourguiba, and some other industries (iron and steel plant, cement factory, refinery) established on its shoreline (Essid and Aissa 2002).

Most studies are carried out on invertebrates in the northern Mediterranean lagoon (Migné and Davoult 1997; Danesi et al. 1999; Mizzan 1999; Kevrekidis et al. 2000). In Tunisia, information on lagoonal invertebrate biodiversity is relatively scarce (Diawara et al. 2008; Tlig-Zouari and Maamouri-Mokhtar 2008; Tlig-Zouari et al. 2009; Afli et al. 2009).

\section{实}

() 2015 Zaabar et al.; licensee Springer. This is an Open Access article distributed under the terms of the Creative Commons Attribution License (http://creativecommons.org/licenses/by/4.0), which permits unrestricted use, distribution, and reproduction in any medium, provided the original work is properly credited. 
Amphipods represent one of the most important groups of invertebrates associated with algae and seagrass, playing an important link in trophic webs from producers to higher consumers such as fish populations (Sanchez-Jerez et al. 1999; Zakhama-Sraieb et al. 2006; Fernandez-Gonzalez and Sanchez-Jerez 2014). Moreover, this fauna is sensitive to environmental conditions and therefore constitutes a good bioindicator of pollution (Bellan-Santini 1980; Virnstein 1987; Conradi et al. 1997; Guerra-Garcia and Garcia-Gomez 2001). Amphipods have proven to be a difficult group to identify due to their small size and morphology; they are however scantily sampled and studied in the lagoon systems (Diviacco and Bianchi 1987; Procaccini and Scipione 1992).

The present study focuses on the dynamics during an annual cycle, with the aim to assess the influence of plant biomass and abiotic factors on the dynamics of amphipod assemblages in the Bizerte lagoon. The selected location appears suitable to analyze the temporal distribution of amphipods and the possible influence of some environmental factors on them. Results will be compared with similar studies on other Mediterranean lagoons. Our hypotheses are that algae and seagrass of the Bizerte lagoon function as a refuge for the amphipod assemblages and that they may change during the year in relation to environmental factors.

\section{Methods}

\section{Area of study}

The Bizerte lagoon is located in the northeast part of Tunisia, between latitudes: $37^{\circ} 8^{\prime} \mathrm{N}$ and $37^{\circ} 14^{\prime} \mathrm{N}$, and longitudes: $9^{\circ} 46^{\prime} \mathrm{E}$ and $9^{\circ} 56^{\prime} \mathrm{E}$ (Figure 1). It covers an area of $130 \mathrm{~km}^{2}$ and has a mean depth of $7 \mathrm{~m}$. It is known for its geostrategic position since it is connected to the Mediterranean Sea through a $6 \mathrm{~km}$ long inlet and to the Ichkeul Lake through the Tinja channel, which is approximately $5 \mathrm{~km}$ long and a few meters in depth (3 $\mathrm{m}$ in the overflow period). The tide undergoes changes in the water level of the Mediterranean, while that own Bizerte lagoon is negligible (Chebbi 2010). The lagoon lies in the vicinity of several cities (Bizerte, Zarzouna, Menzel Abderrahmen, Menzel Jemil, and Menzel Bourguiba) and industrial units.

Sampling was performed in Menzel Jemil (37 $13^{\prime} 2^{\prime \prime}$ $\left.\mathrm{N} 9^{\circ} 55^{\prime} 8^{\prime \prime} \mathrm{E}\right)$ in the northeast of Bizerte lagoon from October 2009 to September 2010 where algae and seagrass were developed during all the years. In this station, the bottom is sandy to sandy-mud.

\section{Sampling procedure}

The benthic macrofauna was sampled monthly during 1 year (from October 2009 to September 2010) using a metal quadrat of $25 \times 25 \mathrm{~cm}$ with 12 replicates between 20 and $80 \mathrm{~cm}$ depth according to the tide. Those replicates were taken from one sampling site in Menzel Jemil and separated from a minimum of $2 \mathrm{~m}$. Specimens were collected from a mix of algae Gracilariopsis longissima (S.G. Gmelin) M. Steentoft, L.M. Irvine \& W. F. Farnham 1995, Gracilaria bursa-pastoris (S.G. Gmelin) P. C. Silva 1952, Cladophora sp., Ulva lactuca (Linnaeus, 1753), and seagrass Cymodocea nodosa (Ucria) Ascherson, 1870. Animals were removed by washing the vegetation in a big tray and recovered on a sieve of a $1 \mathrm{~mm}$ mesh, which retained all individuals including amphipods. Retained specimens were sorted, fixed in 70\% alcohol, and then identified to species and counted. After that, the plant biomass was estimated by weighting algae and seagrass after being dried at $70^{\circ} \mathrm{C}$ for $48 \mathrm{~h}$.

A trophic guild analysis was done attributing the identified species to trophic categories, according to the literature (Guerra-Garcia et al. 2014) as follows: S, suspension feeders; DS, deposit-suspension feeders; He, herbivores; De, plant detritus feeders; and $\mathrm{O}$, omnivores.

\section{Experimental observation}

The following parameters were measured monthly in situ: temperature $(T)$, salinity $(S), \mathrm{pH}$, dissolved oxygen $\left(\mathrm{O}_{2}\right)$, and turbidity $(\mathrm{Tr})$. Temperature, salinity, $\mathrm{pH}$, and dissolved oxygen were measured at approximately $10 \mathrm{~cm}$ below the surface using a salinometer (WTW Cond 315i, SUNTEX, Weilheim, Germany), a $\mathrm{pH}$ meter ( $\mathrm{pH}$ 330i/SET, SUNTEX, Weilheim, Germany) and oximeter (WTW Oxi315i/SET, SUNTEX, Weilheim, Germany) calibrated beforehand. The laboratory analysis of the surface water samples (at $10 \mathrm{~cm}$ ) was performed for nitrites $\left(\mathrm{NO}_{2}^{-}\right)$, nitrates $\left(\mathrm{NO}_{3}^{-}\right)$, and phosphorous $\left(\mathrm{PO}_{4}{ }^{3-}\right)$. The chlorophyll $a(\mathrm{Chl} a)$ content was determined using the spectrophotometric method of Lorenzen (1967) and following the procedure given by Parsons et al. (1984) after $24 \mathrm{~h}$ extractions in $90 \%$ acetone at $5^{\circ} \mathrm{C}$ in the dark.

\section{Data analysis}

To evaluate the importance of the different species, (i) the total abundance (over the study period) (Ni) and monthly mean abundances, (ii) the total dominances (Di\%), and (iii) the frequencies $(\mathrm{Ci})$ were estimated.

The mean density (individuals. $\mathrm{m}^{-2}$ ) was calculated for each month. Collections in April to September were grouped and considered as samples from the dry season, whereas collections in December to March were considered as samples from the rainy season.

Total abundance of amphipod $(N)$, number of species $(S)$, Shannon-Wiener diversity index $\left(H^{\prime}\right)$ (Shannon and Weaver 1963), and Pielou's evenness index $\left(J^{\prime}\right)$ (Pielou 1966) were monthly calculated. Non-metric multidimensional scaling (MDS) (Kruskal and Wish 1978) were performed based on mean abundance of species at each sample. 


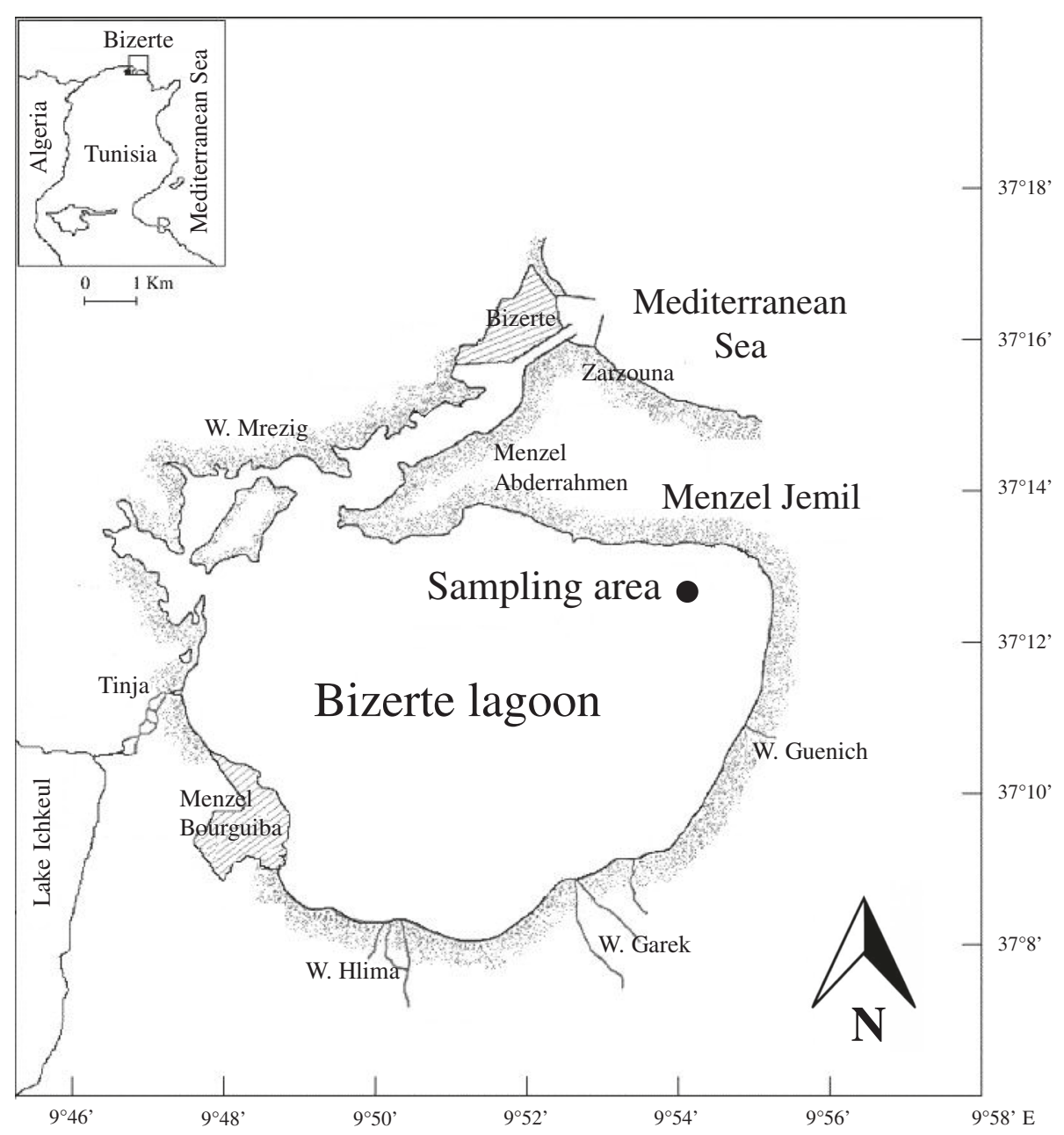

Figure 1 Map of the Bizerte lagoon area showing the location of the study site (Menzel Jemil) and wadis (W).

To investigate the relationship between the environmental variables and the species abundance data, the canonical correlation analysis (CCA) (Anderson and Willis 2003), extremely informative, was applied to the data to show which was the most contributed parameter in the differences reported among samples. The analysis was performed using PRIMER v5.2 (Plymouth Routines of the Multivariate Ecological Research software package) (Clarke and Warwick 1994) and XLSTAT 2013.

\section{Results}

\section{Vegetal composition}

The biomass of each plant species (Table 1) collected during an annual cycle shows a seasonal variation. In fact, the biomass of G. bursa-pastoris is maximized in the spring while that of $U$. lactuca peaked in summer (68.6 g.m ${ }^{-2}$ in August). Regarding Cladophora sp., it appears in winter, when the three algae biomass decreases and reappears in summer with the proliferation of $U$. lactuca. The seagrass $C$. nodosa is present all year, and its biomass reaches a maximum in autumn $\left(38.48 \mathrm{~g} \cdot \mathrm{m}^{-2}\right.$ in November).

The highest total plant biomass was recorded in early summer reaching 127.12 g.m ${ }^{-2}$ in June, followed by spring and autumn, whereas the lowest one was reported in winter (23.11 g.m ${ }^{-2}$ in January), showing a clear seasonal trend (Table 1).

\section{Abiotic factors}

Due to the connection of the Bizerte lagoon to the Mediterranean Sea from the north and to the Ichkeul Lake from the south, the exchange of seawater and the freshwater impact from wadi runoff defines the brackish characteristics and the presence of seasonal spatial gradients in the distribution of the abiotic and biotic variables inside the lagoon. In the present study, the term wadi means a temporary or permanent watercourse, whose flow depends on rains. The principal wadis which feed the Bizerte lagoon with freshwater are the wadis of Mrezig, Hlima, Garek, Guenich, and the channel of 
Table 1 Monthly variation of total plant biomass $\left(g D W . m^{-2}\right)$ and amphipod abundance and values of Shannon-Wiener $\left(H^{\prime}\right)$ and evenness indexes $\left(J^{\prime}\right)$

\begin{tabular}{|c|c|c|c|c|c|c|c|c|c|c|c|c|c|c|c|c|c|}
\hline & October & November & December & January & February & March & April & May & June & July & August & September & $\mathrm{Ni}$ & $\mathrm{Di}$ & $\mathrm{Ci}$ & $\mathrm{Ci} \times \mathrm{Di}$ & $\overline{\text { TG }}$ \\
\hline \multicolumn{18}{|l|}{ Macroalgae and seagrass } \\
\hline Ulva lactuca & 4 & 7 & 5.15 & 2.11 & 3 & 3 & 8 & 10.73 & 60 & 66.10 & 68.60 & 30 & & & & & \\
\hline Cladophora sp. & 0 & 0 & 7 & 2 & 3 & 3.73 & 0 & 0 & 8 & 11 & 0 & 0 & & & & & \\
\hline Gracilariopsis longissima & 1 & 4 & 0 & 3 & 14 & 20 & 27 & 30 & 20.10 & 11.01 & 8 & 9.08 & & & & & \\
\hline Gracilaria bursa-pastoris & 1 & 4 & 0 & 4 & 15 & 20 & 30.18 & 32 & 23 & 11.10 & 8.01 & 9 & & & & & \\
\hline Cymodocea nodosa & 38 & 38.48 & 30 & 12 & 8 & 7 & 8 & 8 & 16.2 & 17 & 17 & 37.08 & & & & & \\
\hline Monthly total biomass & 44 & 61.48 & 41.15 & 23.11 & 44 & 53.73 & 73.18 & 80.73 & 127.12 & 116.21 & 96.7 & 85.16 & & & & & \\
\hline \multicolumn{18}{|l|}{ Amphipods } \\
\hline Gammarus aequicauda (Martynov, 1931) & 99 & 199 & 87 & 111 & 128 & 132 & 320 & 165 & 172 & 116 & 41 & 233 & 1,803 & 49.80 & 1 & 49.80 & De \\
\hline Gammarus insensibilis Stock, 1966 & 89 & 19 & 38 & 113 & 92 & 11 & 89 & 12 & 18 & 13 & 6 & 94 & 594 & 16.40 & 1 & 16.40 & De \\
\hline Gammarella fucicola (Laech, 1814) & & & & & 15 & & 49 & 32 & 18 & 34 & 87 & 81 & 325 & 8.97 & 0.66 & 5.92 & $\mathrm{He}$ \\
\hline Elasmopus rapax Costa, 1853 & 9 & 1 & & & & 5 & & & & & & & 15 & 0.41 & 0.25 & 0.10 & S \\
\hline Monocorophium acherusicum (Costa, 1853) & 7 & 3 & & & & & 1 & & & & & 4 & 15 & 0.41 & 0.33 & 0.13 & Ds \\
\hline Ericthonius difformis (Milne-Edwards, 1830) & 21 & 20 & 28 & 67 & 11 & 48 & 8 & 14 & 8 & 32 & 29 & & 286 & 7.90 & 0.91 & 7.18 & Ds \\
\hline Cymadusa filosa Savigny, 1816 & 13 & 19 & 12 & 6 & & 15 & 5 & 14 & & 153 & 159 & 84 & 480 & 13.26 & 0.66 & 8.75 & $\mathrm{He}$ \\
\hline Microdeutopus gryllotalpa Costa, 1853 & & & & & & & 5 & 10 & 1 & 9 & & 9 & 34 & 0.94 & 0.41 & 0.38 & $\mathrm{He}$ \\
\hline Dexamine spinosa (Montagu, 1813) & & & & & & & 11 & 10 & 4 & 42 & & & 67 & 1.85 & 0.33 & 0.61 & De \\
\hline Caprella sp. (Laech, 1814) & & 1 & & & & & & & & & & & 1 & 0.02 & 0.08 & 0.00 & $\mathrm{O}$ \\
\hline N & 238 & 262 & 165 & 297 & 246 & 220 & 488 & 257 & 221 & 399 & 322 & 505 & 3,620 & 100 & & & \\
\hline$H^{\prime}$ & 2.19 & 1.53 & 1.70 & 1.54 & 1.37 & 1.05 & 1.74 & 1.74 & 1.03 & 1.92 & 1.68 & 1.98 & & & & & \\
\hline$J^{\prime}$ & 0.78 & 0.54 & 0.85 & 0.97 & 0.68 & 0.45 & 0.58 & 0.62 & 0.4 & 0.74 & 0.72 & 0.76 & & & & & \\
\hline
\end{tabular}


Tinja (Figure 1). In rainy seasons, autumn, winter, and early spring, the winds induce a vertical mixture of the water column, the rains are strong, and the freshwater flow coming from the Ichkeul Lake is important. On the other hand, in summer, the dry season, the influence of seawater is important and the water column warming can induce its stratification.

Physical properties, temperature, and salinity of the Bizerte lagoon varied, depending on rainy season and atmospheric forcing (Table 2). Water temperature and salinity ranged from $9^{\circ} \mathrm{C}$ in January to $30.86^{\circ} \mathrm{C}$ in August and from 30.8 psu in February to 39.2 psu in August, respectively, indicating a seasonal gradient of temperature and salinity in this lagoon. However, dissolved oxygen content showed an obvious seasonal variation from $4.8 \mathrm{mg} . \mathrm{l}^{-1}$ in October (autumn) to $7.3 \mathrm{mg} . \mathrm{l}^{-1}$ in May (spring). The turbidity varied from 2.1 NTU in April (spring) to 15.44 NTU in October (autumn). The high nitrogen anion content $\left(\mathrm{NO}_{3}^{-}\right.$and $\left.\mathrm{NO}_{2}^{-}\right)$, measured during the sampling period, was about $3.7 \mu \mathrm{mol}^{-\mathrm{l}^{-1}}$ in winter. The maximum phosphorous content was about $0.38 \mu \mathrm{mol} . \mathrm{l}^{-1}$ in August. The Chl $a$ content ranged between $3.3 \mu \mathrm{g} . \mathrm{l}^{-1}$ in April and $6.3 \mu \mathrm{g} . \mathrm{l}^{-1}$ in August.

Except for the $\mathrm{pH}$, homogeneous during the sampling period, the temperature, salinity, dissolved oxygen, and turbidity fluctuated with season (Table 2). In fact, the winter cold and wet conditions decrease the water temperature and salinity at $9^{\circ} \mathrm{C}$ and $30.86 \mathrm{psu}$, respectively. In summer, the hot and dry conditions lead to the opposite situation because of evaporation $\left(30.86^{\circ} \mathrm{C}\right.$ and $39.2 \mathrm{psu})$.

\section{Amphipod assemblages and species affinities}

Results of the frequencies $(\mathrm{Ci})$ are divided into several categories in ascending order of constant according to the Lopez De La Rosa et al. (2006) classification.
Therefore, Caprella sp. ( $\mathrm{Ci}<12 \%)$ is considered as a scarce species; Elasmopus rapax $(13 \% \leq \mathrm{Ci} \leq 25 \%)$ a restricted species; Monocorophium acherusicum, Dexamine spinosa, and Microdeutopus gryllotalpa $(26 \% \leq \mathrm{Ci} \leq 50 \%)$ are common species; and Gammarus aequicauda, Gammarus insensibilis, Gammarella fucicola, Cymadusa filosa, and Ericthonius difformis are constant species $(51 \% \leq \mathrm{Ci} \leq$ $100 \%)$. According to the $\mathrm{Ci} \% \times \mathrm{Di} \%$ values $(>5)$, the most important species in the amphipod assemblage are $G$. aequicauda, G. insensibilis, G. fucicola, E. difformis, and C. filosa, representing $88.074 \%$ of the total number of specimens.

Our results showed that seasons have a noticeable effect on the amphipod assemblage structure, at the Menzel Jemil station, affecting species richness, mean density, and diversity. Caprella sp. was absent in the samples except in November, where the presence of one specimen was probably due to the frequent tides in autumn. Although they are typical lagoon species, $M$. acherusicum and E. rapax were rarely observed in Menzel Jemil. In fact, the presence of the two species D. spinosa and M. gryllotalpa is limited to the spring period during which the Gracilaria are dominant. However, E. difformis, C. filosa, G. insensibilis, and G. aequicauda were collected throughout the sampling period and whatever the season, with varied abundance. The presence of these species coincides with that of the seagrass $C$. nodosa and the macrophyte $U$. lactuca.

The monthly species richness fluctuated between 3 and 8 in January and April, respectively (Figure 2). The lowest species richness was recorded in winter.

In fact, during the most part of the study period, the mean density according to the four depths (20,40, 60, and $80 \mathrm{~cm}$ ) exhibited a similar evolution to the species richness (Figure 2). In December, the mean density showed the lowest value and then increased from spring to summer. Shannon-Wiener diversity ranged between

Table 2 Monthly variation of physicochemical parameters of water in Menzel Jemil during the sampling period

\begin{tabular}{|c|c|c|c|c|c|c|c|c|c|}
\hline Months & $T\left({ }^{\circ} \mathrm{C}\right)$ & $S$ (psu) & $\mathrm{pH}$ & $\mathrm{O}_{2}\left(\mathrm{mg} . \mathrm{I}^{-1}\right)$ & $\operatorname{Tr}$ (NTU) & $\mathrm{NO}_{2}{ }^{-}\left(\mu \mathrm{M} . \mathrm{I}^{-1}\right)$ & $\mathrm{NO}_{3}^{-}\left(\mu \mathrm{M} . \mathrm{I}^{-1}\right)$ & $\mathrm{PO}_{4}^{3}\left(\mu \mathrm{M} . \mathrm{I}^{-1}\right)$ & Chl $a\left(\mu \mathrm{g} . \mathrm{I}^{-1}\right)$ \\
\hline October & 19.73 & 35.40 & 7.90 & $(4.80)$ & (15.44) & 0.50 & 1.60 & 0.13 & 5.00 \\
\hline November & 13.25 & 34.60 & 8.30 & 4.90 & 14.06 & 0.69 & 1.80 & 0.14 & 4.40 \\
\hline December & 10.00 & 31.80 & 8.39 & 5.90 & 4.70 & 0.49 & 2.00 & 0.16 & 4.20 \\
\hline January & $(9.00)$ & 32.00 & 8.62 & 6.70 & 4.17 & 0.43 & 2.10 & 0.2 & 4.00 \\
\hline February & 11.20 & $(30.80)$ & 8.65 & 6.50 & 3.01 & 0.50 & $(3.20)$ & 0.18 & $(3.80)$ \\
\hline March & 15.10 & 31.10 & 8.62 & 6.00 & 2.45 & 0.57 & 3.00 & 0.24 & 4.50 \\
\hline April & 26.13 & 36.80 & 8.20 & 5.50 & $(2.10)$ & 0.30 & 1.80 & 0.23 & 5.30 \\
\hline May & 25.63 & 37.20 & 8.30 & $(7.30)$ & 5.12 & 0.28 & 1.70 & 0.26 & 4.70 \\
\hline June & 27.73 & 37.90 & 8.10 & 6.70 & 4.76 & $(0.10)$ & 1.00 & 0.27 & 5.00 \\
\hline July & 28.46 & 39.00 & 8.20 & 5.70 & 6.42 & 0.70 & 0.81 & 0.28 & 5.70 \\
\hline August & (30.86) & (39.20) & 8.10 & 5.90 & 3.20 & $(1.00)$ & $(0.73)$ & 0.38 & (6.30) \\
\hline September & 26.70 & 38.60 & 8.38 & 5.60 & 6.18 & 0.49 & 1.40 & 0.12 & 5.40 \\
\hline
\end{tabular}

For each parameter, maximum and minimum values were indicated in italic and in parentheses. 


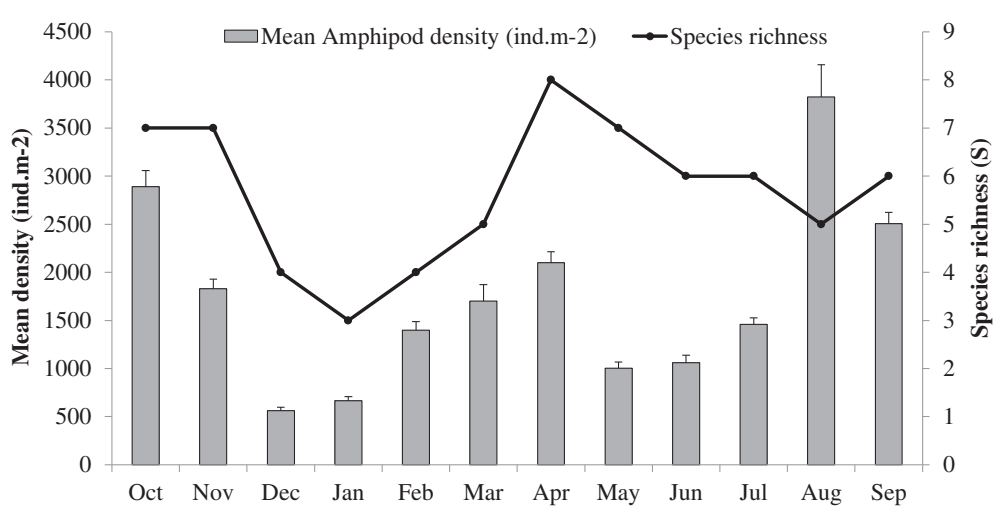

Figure 2 Monthly mean density and species richness of amphipods between October 2009 and September 2010.

1.03 bits in June and 2.19 bits in October. However, eveness index $\left(J^{\prime}\right)$ showed low values in June (0.4) and peaked in January (0.97) (Table 1).

\section{Relationships between amphipod fauna and environmental variables}

MDS ordination plot based on the mean species density revealed three distinct groups of samples corresponding to different periods of the year (Figure 3). Group I included the samples of October and November (autumn), in which species richness and Shannon index were higher. G. aequicauda and G. insensibilis exhibited the most important mean density in this group. Group II was made up of months from December to March (winter) in which greater mean densities of G. aequicauda and $E$. difformis were found with decrease of species richness and increase of mean evenness index $\left(J^{\prime}\right)$. Group III, composed of months from April to September (spring and summer), has a greater mean density of C. filosa. The number of species increased and peaked in April.

According to the results of canonical correspondence analysis between amphipods species and environmental variables, the first two axes accounted for $77.95 \%$ of the variance of species-environment relation (Figure 4). Forward selection in this analysis selected water chlorophyll $a$ content, turbidity, and temperature as the variables explaining most of the variance in the species data $(p<0.01)$. Nitrate concentration, $\mathrm{pH}$, and salinity had less influence on the system, while nitrite and phosphate concentrations and dissolved oxygen had a minimal influence. The ordination showed that temperature, dissolved oxygen, and nitrite concentration were related to axis $\mathrm{F} 1$ and that $\mathrm{pH}$, salinity, and chlorophyll $a$ content, phosphate and nitrate concentrations, and turbidity were related to axis F2 (Table 3).

G. fucicola and M. gryllotalpa were associated with chlorophyll $a$ content and $\mathrm{pH}$. C. filosa was related to high values of temperature and salinity. G. aequicauda was associated with turbidity and nitrate concentration.
Dominant feeding guilds in all studied period were herbivores and plant detritus feeders (three species) followed by deposit-suspension feeders (two species), but suspensivores and omnivores were only represented with one species each (Table 1). Herbivores reached their highest values in summer, represented by G. fucicola and $C$. filosa; however, plant detritus feeders were abundant in autumn and represented by the genus Gammarus.

\section{Discussion}

The vegetation in Menzel Jemil consists essentially of five species with a seasonal variation in their distribution. Indeed, G. longissima and G. bursa-pastoris dominate other species in the spring, U. lactuca whose biomass increases from the spring peaked in summer, Cladophora sp. appears in the winter, while C. nodosa, all year round, dominates in autumn. The temporal distribution of $G$. bursa-pastoris and $U$. lacuta in Menzel Jemil station is similar to that described by Sahli-Hazami (2004). In the lagoon of Venice, Italy, Fava et al. (1992) describe another seasonal succession of vegetation cover which consists mainly of Ulva rigida; the G. bursa-pastoris is present during the cold season, Cladophora sp. is occasional, and marine phanerogam Zostera noltii is found in limited fields.

Plant species richness in the Menzel Jemil station is lower than that described by Zaouali (1980) and Frisoni et al. (1986) in the lagoon of Bizerte; this could be due to eutrophication resulting in the presence of Ulva lacuta (Anonyme 2000), or the increase in salinity caused a decrease in species diversity (Zaouali 1980).

Monthly plant biomass fluctuates with an increase in early spring, peaking in June, and a decrease in summer. Indeed, the rise in water temperature in the spring causes the increase in plant biomass, but when the temperature reaches its maximum in August, plant biomass starts to decrease to reach the lowest values in winter. Highlighting the close relationship between temperature and plant biomass confirms the work of Antit-Ben Rejeb (2012) which showed the same effect of 


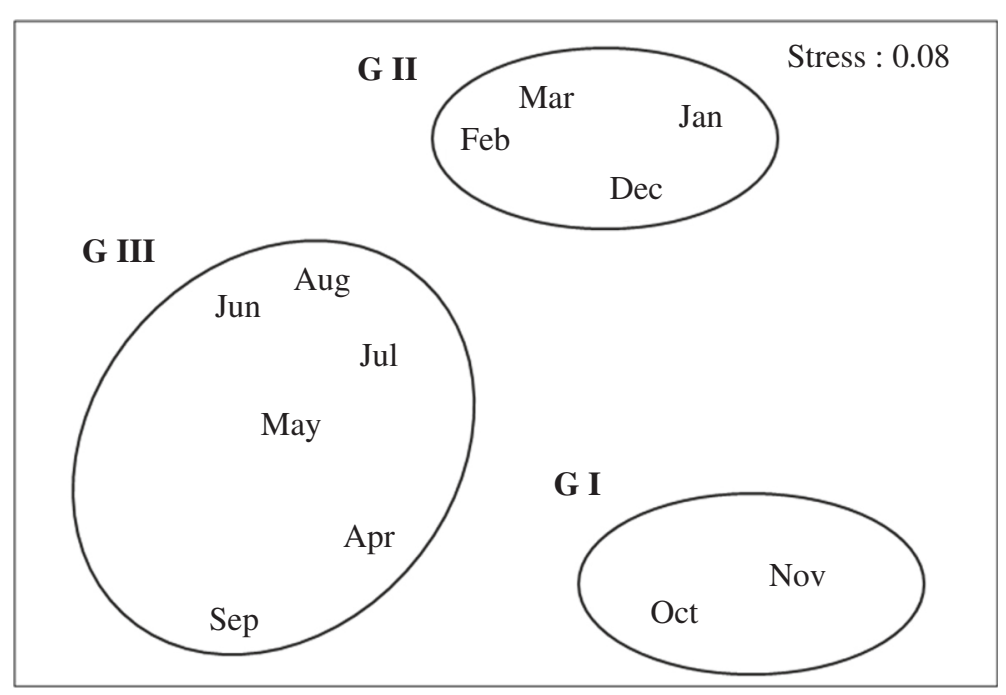

Figure 3 MDS ordination plots based on amphipod abundance of monthly sample.

temperature on the variation of biomass photophilic algae in the bay of Tunis.

In the Bizerte lagoon, water temperature ranges between $9^{\circ} \mathrm{C}$ in January to $30.86^{\circ} \mathrm{C}$ in August. Harzallah (2002) and Béjaoui et al. (2008) reported however a seasonal cycle in the lagoons, ranging between $10^{\circ} \mathrm{C}$ in winter and $28^{\circ} \mathrm{C}$ in summer, and from $11.5^{\circ} \mathrm{C}$ in January to $29.5^{\circ} \mathrm{C}$ in August, respectively. The water salinity ranges from 30.8 in February to 39.2 in August, which is higher than the values reported by ANPE (1990), 30 in winter to 38 in summer (Béjaoui et al. 2005). Thus, seasonal gradients of temperature and water salinity in the Bizerte lagoon are relatively large. Moreover, during the last decade, the temperature and salinity have increased. The evaporation in the lagoon is very important particularly in summer with 166 million $\mathrm{m}^{3}$.year ${ }^{-1}$. Precipitation does not exceed 146 million $\mathrm{m}^{3}$.year ${ }^{-1}$ in winter while it is weak and scarce in summer (74 million $\left.\mathrm{m}^{3} \cdot \mathrm{year}^{-1}\right)$. The water input from the Ichkeul Lake has dramatically decreased during the last decades as an effect of the construction of dams discharging into this lake (MAERH 2003). This has led to a significant alteration of the water characteristics of the lagoon, particularly a dramatic increase in salinity (Béjaoui et al. 2005).

Dissolved oxygen content shows an obvious seasonal variation. Therefore, low water oxygenation logically

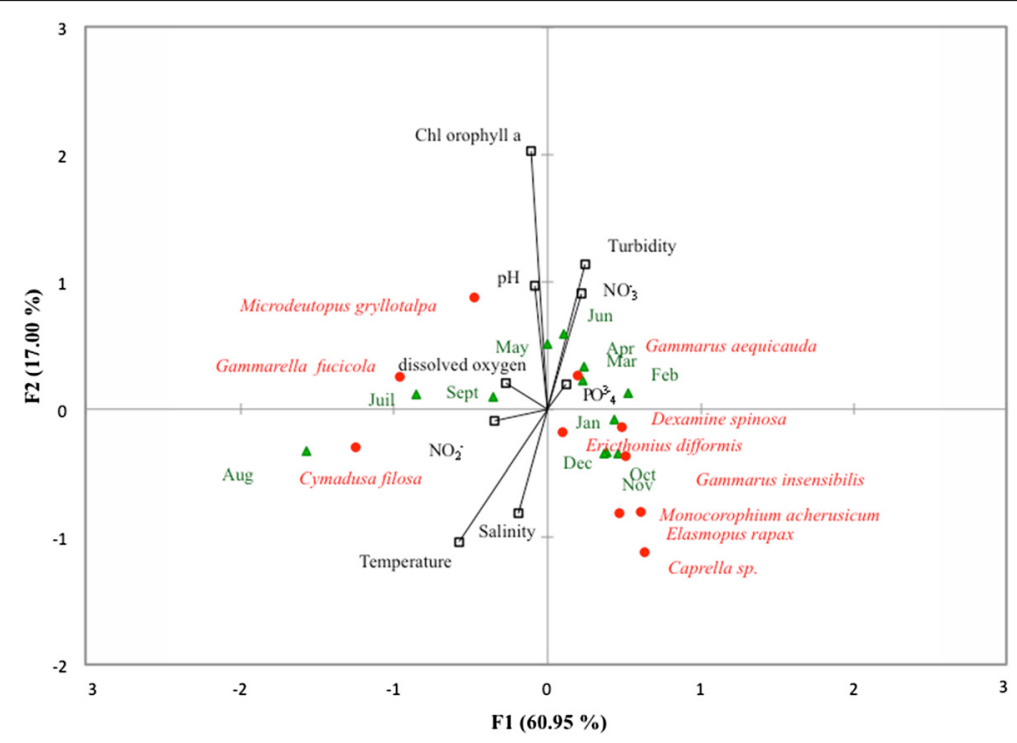

Figure 4 Canonical correspondence analysis ordination of environmental variables and sampled time. Red spot: species; green triangle: month; black square: physicochemical parameter. 
Table 3 CCA: correlation matrix of environmental variables with the first two axes

\begin{tabular}{lll}
\hline & F1 & F2 \\
\hline Temperature $\left({ }^{\circ} \mathrm{C}\right)$ & -0.344 & -0.096 \\
Salinity (psu) & -0.188 & -0.816 \\
Dissolved oxygen $\left(\mathrm{mg} . \mathrm{I}^{-1}\right)$ & -0.273 & 0.209 \\
$\mathrm{pH}$ & -0.079 & 0.964 \\
$\mathrm{Turbidity} \mathrm{NTU})$ & 0.244 & 1.140 \\
$\mathrm{NO}^{-}{ }_{2}\left(\mu \mathrm{mol} . \mathrm{I}^{-1}\right)$ & -0.574 & -1.038 \\
$\mathrm{NO}^{-}{ }_{3}\left(\mu \mathrm{mol} . \mathrm{I}^{-1}\right)$ & 0.223 & 0.905 \\
$\mathrm{PO}^{3-}{ }_{4}\left(\mu \mathrm{mol} . \mathrm{I}^{-1}\right)$ & 0.119 & 0.195 \\
$\mathrm{Chl}^{a}\left(\mu \mathrm{g} . \mathrm{I}^{-1}\right)$ & -0.106 & 2.022 \\
\hline
\end{tabular}

characterizes the dry period. These results agree with those of Béjaoui et al. (2008). Nutrient variability appears to be related to two factors, by seawater coming from the ship canal and also by freshwater coming from the Ichkeul Lake and its large catchment area. The high nitrogen anion concentrations $\left(\mathrm{NO}_{3}^{-}\right.$and $\left.\mathrm{NO}_{2}^{-}\right)$and phosphorous content can be related to the domestic sewage input from towns around the lagoon and specially Menzel Abderrahmen city or to the freshwater from Oued Guenich located on the eastern side of the Bizerte lagoon which is widely open to an agricultural zone where fertilizers are constantly applied. These factors may provide the explanation of the various content of chlorophyll $a$ during the sampling period. However, the turbidity appears to be related to two factors, (i) hydrodynamic conditions and (ii) rainy season, which create water movements. Indeed, studies performed by Harzallah (2003) on the currents of the Bizerte lagoon reveal that the flow of water in both the surface and the bottom follows the wind direction, which is often northwest with low amplitude. Nevertheless, the interpretation of these results must take into account the special conditions of the Bizerte lagoon, which is a transitional area currently affected by many environmental variables (Afli et al. 2008). Moreover, nutrients and chlorophyll $a$ concentrations recorded during the sampling period are lower than those observed before the connection of the urban and industrial waste to the ONAS network (National Sanitation Utility) (MAERH 2003; Béjaoui et al. 2008). Besides, coastal lagoons are considered to be highly productive ecosystems but they are vulnerable to human disturbance as a result of their semi-enclosed situation and their proximity to the sources of terrestrial effluents (Bazairi et al. 2005).

In Menzel Jemil (Bizerte lagoon, Tunisia), 3,620 specimens of amphipods were collected from October 2009 to September 2010 belonging to 8 families and 9 genera; the species are common in Tunisian lagoons (Diawara et al. 2008; Zakhama-Sraieb et al. 2009). Differences in the abundance of the ten species were observed. While G. aequicauda was the most abundant, G. fucicola, C. filosa, and Caprella sp. were recorded for the first time in the Bizerte lagoon. M. gryllotalpa was typically a lagoonal species. Compared to Diawara et al. (2008), the number of amphipod species herein recorded is lower than that found in the Tunis north lagoon; however, a relatively high number of amphipod species are found in the coastal lagoon of Smir (northwest of Morocco) by Chaouti and Bayed (2011), by Cherkoui et al. (2003) in the Bou Regreg estuary Moroccan Atlantic coast, and by Mogias and Kevrekidis (2005) in the Laki lagoon (Northern Aegean).

Our results show that the distribution of the amphipod fauna in the Bizerte lagoon is primarily linked to temperature and salinity. Oscillations in these environmental variables are related to the climatic season. An increase in temperature and salinity is characteristic of the dry season (summer), when the seawater penetrates the lagoon in a greater volume as a result of reduced rainfall, whereas in the wet season (winter), freshwater comes from rivers and the Ichkeul Lake and thereby reduces salinity. These results agree with studies on distribution patterns for other crustaceans in relation to the temperature and salinity of the water, which are considered extremely important for a better understanding of the dynamics of these species (Pinheiro 1991). Variations in temperature and salinity have been cited by a number of authors as important factors for the occurrence of particular amphipod species (Nevis et al. 2009; Mogias and Kevrekidis 2005). In fact, many ecological studies have shown salinity to be the main factor controlling zonation in the structure of the benthic communities (Cacabelos et al. 2010). However, Bazairi et al. (2003) have emphasized that this is not the main factor in brackish environments. Some other authors have demonstrated that modification in habitat complexity affects crustacean assemblages (Sanchez-Jerez et al. 1999; Ayala and Martin 2003; Vazquez-Luis et al. 2008). Indeed, the importance of temperature should be interpreted carefully, since Ysebaert and Herman (2002) pointed out that longterm averages of environmental variables are more important than values obtained during samplings (Cacabelos et al. 2010). Nevertheless, the difference in mean density between months can be explained by the ecological preferences of each species. Amphipod assemblages at the Bizerte lagoon are dominated in terms of density and species richness by the genus Gammarus. The temporal variability of the total density is mainly due to the numerically dominant species, such as G. aequicauda, G. insensibilis, and C. filosa. The seasonal variation in mean density recorded from our study area was similar to that described in other Mediterranean lagoons (Mogias and Kevrekidis 2005; Procaccini and 
Scipione 1992). With respect to changes in algae and seagrass, which create refuge and food resource to diverse amphipods, an important reduction in species richness was recorded in January in our study contrary to Mogias and Kevrekidis (2005) in July.

Concerning the diversity of the communities, the diversity index $\left(H^{\prime}\right)$ and evenness $\left(J^{\prime}\right)$ values are low in the different seasons. Moreover, abundance and species richness values showed a sharp decrease during December, January, and February when both temperature and salinity diminish, whereas equitability and Shannon-Wiener indexes in the studied amphipod assemblage are more stable over time than those found in other areas.

The temporal distribution of amphipod assemblage studied by analyses of similarity between the samples, based on the abundance of species, exhibited three major assemblages whose distribution is strongly dependent on the water temperature and shows a seasonal pattern. Similar distribution patterns for amphipods and other crustaceans have been reported in several studies (Bazairi et al. 2003; Mogias and Kevrekidis 2005; Lopez De La Rosa et al. 2006; Vazquez-Luis et al. 2008; Nevis et al. 2009; Cacabelos et al. 2010; Zakhama-Sraieb et al. 2010). In fact, canonical correspondence analysis (CCA) made it possible to summarize the overall situation for the species, sampling months, and environmental parameters on a single graph. In accordance with our results, the temperature, turbidity, and chlorophyll $a$ content are the most often reported factors in determining the distribution and composition of amphipods in Menzel Jemil. However, phosphate and nitrite concentrations do not show large variability. Thus, amphipod assemblages are probably not very influenced by their modest variations. On the other hand, these changes in environmental factors in this study may affect algae and seagrass which are support of the amphipod assemblages.

Amphipods play an important role in structuring benthic assemblages (Duffy and Hay 2000) as secondary and tertiary producers in marine communities (Beare and Moore 1996). Amphipods are important source of food for benthic fauna of commercial interest and also very ecologically sensitive organisms and good indicators of natural or disturbed environmental conditions (Conradi et al. 1997). Moreover, benthic databases are essential for comparisons valuable for impact studies or monitoring programs, in order to preserve the environment and the species of commercial importance that they support (Desroy et al. 2002).

\section{Conclusions}

A total of 3,620 amphipod individuals were collected in Menzel Jemil (Bizerte lagoon, Tunisia) belonging to ten species. G. aequicauda was the most abundant species, and G. fucicola, C. filosa, and Caprella sp. were recorded for the first time in the Bizerte lagoon. The diversity index $\left(H^{\prime}\right)$ and evenness $\left(J^{\prime}\right)$ values are low in the different seasons, while abundance and species richness values showed a sharp decrease during December, January, and February when both temperature and salinity diminish. According to canonical correspondence analysis, the temperature, turbidity, and chlorophyll $a$ content are the most often reported factors in determining the distribution and composition of amphipods in Menzel Jemil.

\section{Competing interests}

The authors declare that they have no competing interests.

\section{Authors' contributions}

All the authors performed the field sampling, participated and coordinated in the design and analysis of the study, and drafted the manuscript. All authors read and approved the final manuscript.

\section{Acknowledgements}

The present study was funded by the Research Unit of Bio-ecology and Evolutionary Systematics (UR11ES11), Faculty of Science of Tunis, University of Tunis El Manar. We would like to thank Miranda Lowe (Natural History Museum of London) for improving the English language.

Received: 13 June 2014 Accepted: 31 March 2015

Published online: 28 April 2015

\section{References}

Afli A, Ayari R, Zaabi S (2008) Ecological quality of some Tunisian coast and lagoon locations, by using benthic community parameters and biotic indices. Estuar Coast Shelf Sci 80:269-280, doi:10.1016/j.ecss.2008.08.010

Afli A, Boufahja F, Sadraoui S, Ben Mustapha K, Aissa P, Mrabet R (2009) Functional organization of the benthic macrofauna in the Bizerte lagoon (SW Mediterranean Sea), semi-enclosed area subject to strong environmental/anthropogenic variations. Cah Biol Mar 50:105-117

Anderson MJ, Willis TJ (2003) Canonical analysis of principal coordinates: a useful method of constrained ordination for ecology. Ecol 84:511-525

Anonyme (2000) Evaluation accélérée du niveau de la mer en Tunisie, vulnérabilité et adaptation. Rapport définitif. TUN/95/G31: Projet National sur les changements climatiques. République Tunisienne, Ministère de l'Environnement et de l'Aménagement du territoire, $119 \mathrm{p}$

ANPE (1990) Etude préliminaire de l'écologie du lac de Bizerte. Rapport, Agence Nationale de Protection de l'Environnement, Tunis, 100 pp

Antit-Ben Rejeb M (2012) Caractérisation des communautés de mollusques dans des milieux littoraux de la baie de Tunis. Thèse de doctorat en sciences. Biologiques, Faculté des Sciences de Tunis, $384 \mathrm{p}$

Ayala Y, Martin A (2003) Relaciones entre la comunidad de anfipodos y las macroalgas a las que estàn asociados, en una plataforma rocosa del litoral central de Venezuela. Bol Inst Esp Oceanogr 19(1-4):171-183

Ayari R, Afli A (2003) Bionomie benthique du petit golfe de Tunis. Bulletin de I'Institut National des Sciences et Technologies de la Mer de Salammbô, Tunisia 30:79-90

Bazairi H, Bayed A, Glémarec M, Hily C (2003) Spatial organisation of macrozoobenthic communities in response to environmental factors in a coastal lagoon of the NW African coast (Merja Zerga, Morocco), Oceanol Acta 26: 457-471. doi:10.1016/S0399-1784(03)00041-0

Bazairi H, Bayed A, Hily C (2005) Structure et bioévaluation de l'état écologique des communautés benthiques d'un écosystème lagunaire de la côte atlantique marocaine. C R Biologies 328:977-990, doi:10.1016/j.crvi.2005.09.006

Beare DJ, Moore PG (1996) The distribution, growth and reproduction of Pontocrates arenarius and P. altamarinus (Crustacea: Amphipoda) at Millport, Scotland. J Mar Biol Ass UK 76:931-950, doi:10.1017/S0025315400040893

Béjaoui B, Ben Charrada R, Moussa M, Ben Hamadou R, Harzallah A, Chapelle A (2005) Caractérisation hivernale de la lagune de Bizerte. Bull Inst Natn Scien Tech Mer de Salammbô 32:79-91

Béjaoui B, Harzallah A, Moussa M, Chapelle A, Solidoro C (2008) Analysis of hydrobiological pattern in the Bizerte lagoon (Tunisia). Estuar Coast Shelf Sci 80:121-129, doi:10.1016/j.ecss.2008.07.011 
Bellan-Santini D (1980) Relationship between populations of amphipods and pollution. Mar Poll Bull 11:224-227

Ben Mustapha K, Hattour A, Mhetli M, El Abed A, Tritar B (1999) Bionomie des étages infra et circalittoral du golfe de Gabès. Bull Inst Natn Scien Tech Mer de Salammbô, Tunisia 26:5-48

Blanchet H, Lavesque N, Ruellet T, Dauvin JC, Sauriau PG, Desroy N, Desclaux C, Leconte M, Bachelet G, Janson AL, Bessineton C, Duhamel S, Jourde J, Mayot S, Simon S, de Montaudouin X (2008) Use of biotic indices in semi-enclosed coastal ecosystems and transitional waters habitats - implications for the implementation of the European Water Framework Directive. Ecol Indic 8:360-372, doi:10.1016/j.ecolind.2007.04.003

Cacabelos E, Lourido A, Troncoso JS (2010) Composition and distribution of subtidal and intertidal crustacean assemblages in soft-bottoms of the Ria de Vigo (NW Spain). Scient Mar 74(3):455-464

Chaouti A, Bayed A (2011) Structure et organisation trophique du peuplement macrobenthique de la lagune méditerranéenne de Smir (Maroc). Bull Inst Sci Rabat 33(1):1-12

Chebbi N (2010) Etude systématique, bio-écologique et chimique des ascidies de Tunisie. Thèse de Doctorat, Institut National Agronomique de Tunisie, 301 p

Cherkoui E, Bayed A, Hilly C (2003) Organisation spatiale des peuplements macrozoobenthiques subtidaux, d'un estuaire de la côte atlantique marocaine. Cah Biol Mar 44:339-352

Clarke KR, Warwick RM (1994) Similarity-based testing for community pattern: the 2way layout with no replication. Mar Biol 118:167-176, doi:10.1007/BF00699231

Conradi M, Lopez-Gonzalez PJ, Garcia-Gomez JC (1997) The amphipod community as a bioindicator in Algeciras Bay (Southern Iberian Peninsula) based on a spatio-temporal distribution. Mar Ecol 18(2):97-111, doi:10.1111/j.1439-0485.1997.tb00430.x

Danesi P, Gola G, Tagnin L (1999) Structure e dinamiche del macrobenthos ai confini dei partiacque nel bacino centrale della laguna di Venezia. In: Bon M., Sburlino G. And Zcarello V. (eds), Aspetti Ecologici et Naturalistici dei sistemi lagunairi e Costieri. Atti13. Conv. Gruppo Ecologia di Base "G. Gardio" Venezia 267-269

Dellali M, Elbour M, Aïssa P (2001) Evaluation de la pollution bactérienne dans la lagune de Bizerte : Résultats préliminaires. J Rech Oceanogr 26:18-28

Desroy N, Warembourg C, Dewarumez JM, Dauvin JC (2002) Macrobenthic resources of the shallow soft-bottom sediments in the eastern English Channel and southern North Sea. ICES J Mar Sci 60: 120-131. doi:org/10.1006/jmsc.2002.1333

Diawara M, Tlig-Zouari S, Rabaoui L, Ben Hassine OK (2008) Impact of management on the diversity of macrobenthic communities in Tunis north lagoon: systematics. Cah Biol Mar 49:1-16

Diviacco G, Bianchi CN (1987) Fauna interrelationships between lagoonal and marine amphipod crustacean communities of the Po River Delta (Northern Adriatic). Ann Biol (Biologia Ambiental) 12(3):67-77

Duffy JE, Hay ME (2000) Strong impacts of grazing amphipods on the organization of a benthic community. Ecol Monogr 70:237-263

Essid N, Aissa P (2002) Etude quantitative des nématodes libres des secteurs Nord et Est de la lagune de Bizerte (Tunisie). Bull Inst Natn Scien Tech Mer de Salammbô 29:53-63

Fava G, Zangaglia A, Cervelli M (1992) Ecology of Idotea balthica (Pallas) populations in the lagoon of Venice. Oceanol Acta 15(6):651-660

Fernandez-Gonzalez J, Sanchez-Jerez P (2014) First occurrence of Caprella scaura Templeton, 1836 (Crustacea: Amphipoda) on off-coast fish farm cages in the Mediterranean Sea. Helgol Mar Res 68:187-191, doi:10.1007/s 10152-013-0375-y

Frisoni G F, Guelorget O, Pertuisot J P, Fresi E (1986) Diagnose écologique et zonation biologique du lac de Bizerte. Applications aquacoles. Rapport du projet MEDRAP : regional Méditerranean developpement of aquaculture. FAO, $41 \mathrm{p}$

Guerra-Garcia JM, Garcia-Gomez JC (2001) The spatial distribution of Caprellidea (Crustacea: Amphipoda): a stress bioindicator in Ceuta (North Africa, Gibraltar area). Mar Ecol PSZN 22:357-367

Guerra-Garcia JM, Tierno de Figueroa JM, Navarro-Barranco C, Ros M, SanchezMoyano JE, Moreira J (2014) Dietary analysis of the marine Amphipoda (Crustacea: Peracarida) from the Iberian Peninsula. J Sea Res 85: 508-517. doi: org/10.1016/j.seares.2013.08.006

Harzallah A (2002) Etat actuel et évolution de l'exploitation halieutique et aquacole des lagunes - cas de la lagune de Bizerte. Rap Inst Natn Scien Tech Mer de Salammbô

Harzallah A (2003) Transport des polluants dans la lagune de Bizerte simulé par un modèle de circulation de l'eau. Bull Inst Natn Scien Tech Mer de Salammbô 30:115-133
Kevrekidis T, Mogias A, Gouvis N (2000) Interannual changes in the composition of the macrobenthic fauna of Drana lagoon (Evros Delta, N. Aegean Sea): preliminary note. Belg J Zool 130(Suppl 1):101-107

Kruskal JB, Wish M (1978) Multidimensional Scaling. Sage Publications, Beverly Hills, California, $93 p$

Lopez De La Rosa I, Rodriguez A, Garcia Raso JE (2006) Seasonal variation and structure of a decapod (Crustacea) assemblage living in a Caulerpa prolifera meadow in Càdiz Bay (SW Spain). Estuar Coast Shelf Sci 66:624-633, doi:10.1016/j.ecss.2005.11.008

Lorenzen CJ (1967) Determination of chlorophyll and pheopigments by spectrophotometric equations. Limnol Oceanogr 12:343-346

MAERH (2003) Etude sur la dépollution industrielle dans le bassin versant du lac de Bizerte. Rapport, Ministère de l'Agriculture, de l'Environnement et des Ressources Hydrauliques, Tunis, $182 \mathrm{pp}$

Migné A, Davoult D (1997) Distribution quantitative de la macrofaune benthique du peuplement des cailloutis dans le détroit du Pas de Calais (Manche orientale, France). Oceanol Acta 20(2):453-460

Mizzan L (1999) Le specie alloctone del Macrozoobenthos della laguna di Venezia: Il punto della situazione. Boll Mus civ St nat Venezia 49(1998):145-177

Mogias A, Kevrekidis T (2005) Macrozoobenthic community structure in a poikilohaline Mediterranean lagoon (Laki Lagoon, northern Aegean). Helgol Mar Res 59: 167-176. doi:10.007/s10152-004-0215-1

Mouillot D, Laune J, Jean-Antoine Tomasini JA, Aliaume C, Brehmer P, Dutrieux E, Do Chi T (2005) Assessment of coastal lagoon quality with taxonomic diversity indices of fish, zoobenthos and macrophyte communities. Hydrobiologia 550:121-130, doi:10.1007/s10750-005-4368-y

Nevis AB, Martinelli M, Carvalho ASS, Nahum VII (2009) Abundance and spatialtemporal distribution of the family Portunidae (Crustacea, Decapoda) in the Curuça estuary on the northern coast of Brazil. Braz J Aquat Sci Technol 13(1):71-79

Parsons TR, Maita Y, Lalli CM (1984) A manual of chemical and biological methods for seawater analysis. Pergamon Press, Oxford, $173 \mathrm{p}$

Pielou EC (1966) The measurement of diversity in different types of biological collections. J Theor Biol 13:131-144

Pinheiro MAA (1991) Distribuição e biologia populacional de Arenaeus cribrarius (Lamarck, 1818) (Crustacea, Brachyura, Portunidae), na enseada da Fortaleza. Ubatuba, SP. Dissertação de Mestrado. Instituto de Biociências - UNESP, 192 p

Procaccini G, Scipione MB (1992) Observations on the spatio-temporal distribution of crustacean amphipods in the Fusaro coastal lagoon (central Tyrrhenian Sea, Italy) and some notes on their presence in Mediterranean lagoons. Mar Ecol 13:203-224, doi:10.1111/j.1439-0485.1992.tb00351.x

Rossi F, Castelli A, Lardicci C (2006) Distribution of macrobenthic assemblages along a marine gradient in Mediterranean eutrophic coastal lagoons. Mar Ecol 27:66-75

Sahli-Hazami K (2004) Evaluation des potentialités de régénération de l'algue rouge Gracilaria sp. du lac de Bizerte et détermination de sa faune associée. Diplôme d'Etude Approfondes en Ecologie Générale. Faculté des Sciences de Tunis, $108 \mathrm{p}$

Sanchez-Jerez P, Barberà-Cebriàn C, Ramos-Espla AA (1999) Comparison of the epifauna spatial distribution in Posidonia oceanica, Cymodocea nodosa and unvegetated bottoms: importance of meadow edges. Acta Oecolog 20: 391-405. doi:org/10.1016/S1146-609X(99)00128-9

Shannon CE, Weaver W (1963) The mathematical theory of communication. Illinois University Press, Urbana, 117 p

Tlig-Zouari S, Maamouri-Mokhtar F (2008) Macrozoobenthic species composition and distribution in the northern lagoon of Tunis. Transit Waters Bull 2:1-15

Tlig-Zouari S, Mami T, Maamouri F (2009) Structure of benthic macroinvertebrates and dynamics in the northern lagoon of Tunis. J Mar Biol Ass UK 89(7):1305-1318, doi:10.1017/S0025315409000721

Vazquez-Luis M, Sanchez-Jerez P, Bayle-Sempere JT (2008) Changes in amphipod (Crustacea) assemblages associated with shallow-water algal habitats invaded by Caulerpa racemosa var. cylindracea in the western Mediterranean Sea. Mar Environ Res 65:416-426, doi:10.1016/j.marenvres.2008.01.006

Virnstein RW (1987) Seagrass-associated invertebrate communities of the southeastern USA: a review. Fla Mar Res Publs 42:89-116

Ysebaert T, Herman PMJ (2002) Spatial and temporal variation in benthic macrofauna and relationships with environmental variables in an estuarine, intertidal soft-sediment environment. Mar Ecol Prog Ser 244:105-124, doi:10.3354/meps244105

Zakhama-Sraieb R, Sghaier YR, Charfi-Cheikhrouha F (2006) Is amphipod diversity related to the quality of Posidonia oceanica beds? Biol Mar Medit 13:174-180 
Zakhama-Sraieb R, Sghaier YR, Charfi-Cheikhrouha F (2009) Amphipod biodiversity of the Tunisian coasts: update and distributional ecology. JMBA2 Biodiversity Records, 2, e155 doi:10.1017/S1755267209990820 (published online)

Zakhama-Sraieb R, Sghaier YR, Charfi-Cheikhrouha F (2010) Community structure of amphipods on shallow Posidonia oceanica meadows off Tunisian coasts. Helgol Mar Res 65(2):203-212, doi:10.1007/s10152-010-0216-1

Zaouali J (1980) Flore et faune benthiques de deux lagunes tunisiennes: le lac de Bizerte (Tunisie septentrionale) et la mer de Bougrara (Tunisie méridionale). Bull Off natn Pêch Tunisie. Tunisie 4(1):196-200

Submit your manuscript to a SpringerOpen ${ }^{\odot}$ journal and benefit from:

- Convenient online submission

- Rigorous peer review

- Immediate publication on acceptance

- Open access: articles freely available online

- High visibility within the field

- Retaining the copyright to your article

Submit your next manuscript at $\gg$ springeropen.com 